\title{
Pola Asuh Orang Tua pada Anak Usia 10-14 Tahun di Daerah Istimewa Yogyakarta
}

Umi Listyaningsih ${ }^{1}$, Muhammad Arif Fahrudin Alfana ${ }^{1}$, Resti Pujihastuti ${ }^{2}$ dan Hilma Amrullah²

${ }^{1}$ Fakultas Geografi, Universitas Gadjah Mada, Yogyakarta, ${ }^{2}$ Badan Kependudukan dan Keluarga Berencana Nasional, Jakarta

Korespondensi: Umi Listyaningsih (e-mail: umilis@ugm.ac.id)

\begin{abstract}
Abstrak
Usia 10-14 tahun merupakan masa remaja awal dimana usia tersebut merupakan usia persiapan anak saat tumbuh menjadi pribadi yang matang. Oleh sebab itu, pola asuh orang tua yang tepat pada usia ini akan menjadi hal yang penting bagi tahap perkembangan selanjutnya. Tujuan penelitian ini adalah mendeskripsikan pola asuh orang tua pada anak usia 10-14 tahun di Daerah Istimewa Yogyakarta. Penelitian ini menggunakan metode surveidengan sampel sebanyak 150 rumah tangga yang dipilih secara acak. Hasil penelitian ini menunjukkan bahwa pola asuh orang tua di Daerah Istimewa Yogyakarta terdiri atas pola asuh demokratis, otoriter, permisif dan acuh. Berdasarkan keempat pola asuh tersebut, sebagian besar keluarga menyatakan telah menerapkan pola asuh demokratis untuk mendidik anak-anaknya.
\end{abstract}

Kata kunci: pola asuh; remaja; anak 10-14 tahun

\section{Children Aged 10-14 Years Parenting in the Special Region of Yogyakarta}

\begin{abstract}
Children aged 10-14 years are the stages of early adolescence. It is the age of preparation when they grow into mature ones. Parenting at this age will be very important for the next stage of children development. The purpose of the present study is to describe parenting in children aged 10-14 years in Special Region of Yogyakarta. The present study used a survey method with a sample of 150 households chosen randomly. The results indicated that parenting implemented by the families in the Special Region of Yogyakarta consisted of democratic parenting, authoritarian/otoriter parenting, permissive parenting and neglectful parenting. Based on the four types of parenting, most families implemented democratic parenting to raise and care their children.
\end{abstract}

Keywords: parenting; adolescents; children 10-14 years 
Umi Listyaningsih, Muhammad Arif Fahrudin Alfana, Resti Pujihastuti, dan Hilma Amrullah

\section{Pendahuluan}

Daerah Istimewa Yogyakarta (DIY) adalah provinsi dengan pertambahan penduduk yang cepat(Giyarsih danAlfana,2013). Berdasarkan data BPS (2018), pertumbuhan penduduk di DIY sebesar 1 persen per tahun selama kurun waktu 2010-2018. Hal ini menyebabkan jumlah penduduk di DIY terus berubah sepanjang waktu dengan penambahan penduduk mencapai lebih dari 80 ribu jiwa. Selain itu, DIY juga mengalami pencapaian pembangunan manusia yang sangat baik. Indeks Pembangunan DIY selama 2010-2018 terus mengalami peningkatan dan pada 2018 menunjukkan nilai sebesar 79,53 (BPS, 2018). Meski demikian, beberapa permasalahan kependudukan masih terjadi seiring tingginya capaian-capaian indikator pembangunan tersebut. Salah satu permasalahan tersebut adalah masalah kenakalan remaja yang berujung pada kriminalitas.

Darwin, Ekawati dan Khabib (2017) menjelaskan bahwa permasalahan kenakalan remaja berada pada tahap yang menghawatirkan. Salah satu kasus kenakalan remaja yang terkenal di DIY adalah klitih. Kapolda DIY mengatakan bahwa persoalan kenakalan yang disebut klitih menjadi perhatian serius. Pada 2016, klitih di DIY tercatat sebesar 43 kasus dan hal yang memprihatinkan adalah kenakalan tersebut berujung kematian1. Pada 2017, Kapolda menyatakan bahwa Yogyakarta Darurat "klitih". Menguatkan pendapat dari Kapolda DIY tersebut, data di Polda DIY menunjukkan bahwa kriminalitas jalanan dan kenakalan remaja (klitih) menyumbang 70 persen bentuk kenakalan remaja. Sedangkan sisanya adalah kenakalan berupa pembacokan/ remaja-di-yogyakarta-selama-2016-terjadi-43kasus.html pembunuhan, geng sekolah, kekerasan seksual dan bentrokan antarsuporter.

Hasil penelitian Darwin, Ekawati dan Khabib (2017) menjelaskan bahwa sebanyak 65 persen responden setuju bahwa peran orang tua yang lemah menjadi faktor dominan terkait munculnya kekerasan pada remaja di DIY. Artinya, salah satunya alasan kemunculan permasalahan kekerasan tersebut disebabkan oleh kegagalan pola asuh orang tua dalam mendidik anak-anaknya.

Kegagalan pola asuh yang dijalankan orang tua dapat terjadi sejak masa remaja awal. Masa ini, menurut Steinberg (2017), disebut sebagai masa remaja awal (early adolescent) yang terjadi pada anak usia 10-14 tahun. Padahal masa ini merupakan masa anak mulai mencari jati diri atau identitas diri. Jika diarahkan dengan baik, tentu saja perilaku-perilaku negatif anak dapat diminimalisasi.

Penelitian ini berusaha menjelaskan pola asuh anak pada remaja awal yakni usia 10-14 tahun di Daerah Yogyakarta. Deskripsi sederhana ini diharapkan dapat digunakan sebagai dasar awal dalam melihat pola asuh yang lebih mendalam di DIY. Selain itu, penelitian ini juga diharapkan dapat menjadi dasar perumusan pola asuh anak yang ideal dalam mencegah kenakalan anak, khususnya di DIY.

\section{Metodologi}

Penelitian ini merupakan penelitian kuantitatif yang dilakukan dengan metode survei. Populasi penelitian ini adalah keluarga di DIY yang memiliki anak berusia antara 10-14 tahun, baik laki-laki maupun perempuan. Studi kuantitatif berbasis keluarga ini akan menghasilkan data statistik untuk mengidentifikasi jenis dan pola asuh keluarga. 


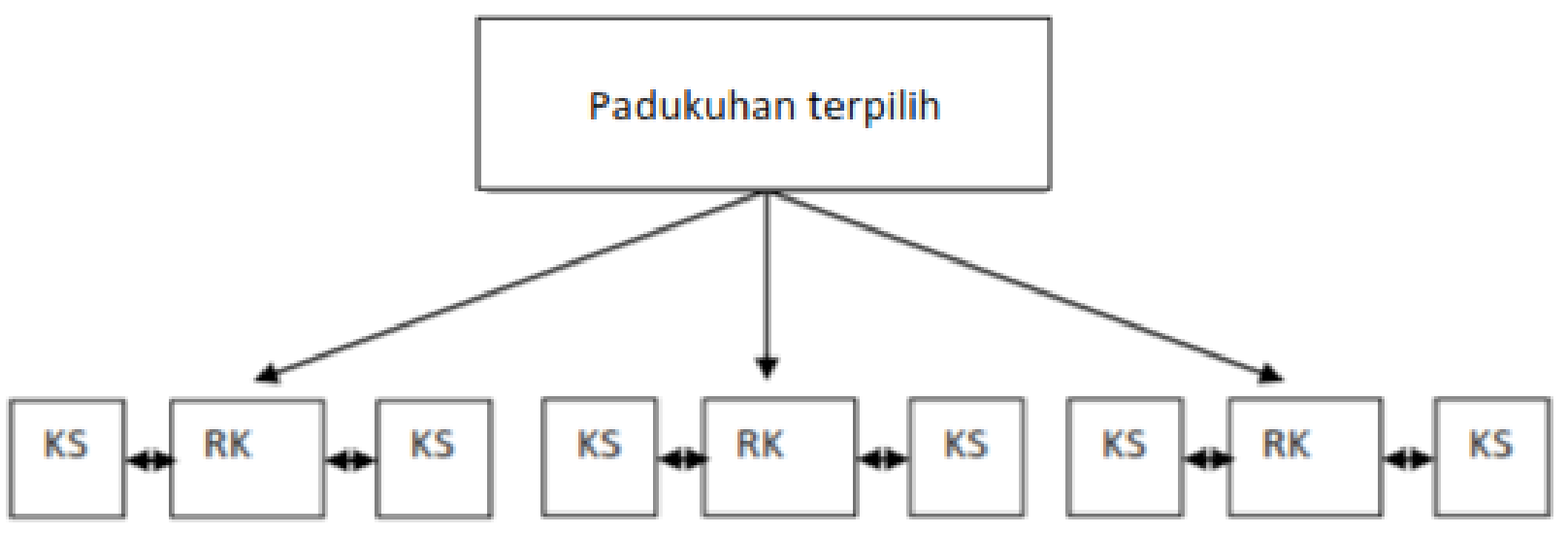

Keterangan:

RK: Keluarga (Responden Kunci) yang memiliki anak 10-14 tahun. Jumlah responden di setiap dukuh adalah 30 responden (total 150 responden di DIY)

KS: Keluarga sekitar responden kunci yang berada di kanan-kiri. Informasi dari KS akan menjadi pengontrol jawaban tentang bagaimana pola asuh RK sehari-hari.

Gambar 1. Gambaran Pengambilan Sampel pada Tingkat Pedukuhan

Responden penelitian ini mencakup keluarga yang memiliki anak berusia 10-14 tahun. Responden anak 10-14 tahun dipilih dengan menggunakan teknik pengambilan sampling acak bertingkat (multistage random sampling) dengan menggunakan kecamatan sebagai cluster yang dipilih pada tahap pertama dan unit keluarga pada tahap terakhir. Jumlah responden pada penelitian ini adalah 150 responden yang tersebar di lima dukuh. Untuk mengontrol kebenaran jawaban responden, peneliti menggunakan metode triangulasi dengan mewawancarai tetangga di sekitar (kanan-kiri) responden utama. Ilustrasi pengambilan sampel pada tingkat pedukuhan dapat dilihat pada Gambar 1.

Lokasi penelitian ditentukan secara sengaja (purposif) di lima dukuh di seluruh Kabupaten/Kota DIY dengan beberapa tahapan dan pertimbangan sebagai berikut:
1. Pada tingkat kecamatan, kecamatan terpilih adalah kecamatan yang memiliki jumlah penduduk usia 10-14 tahun terbanyak di kabupaten/kota di DIY. Berdasarkan tahapan tersebut, kecamatan yang terpilih terdiri atas Kecamatan Cangkringan, Kecamatan Kraton, Kecamatan Saptosari, Kecamatan Bantul dan Kecamatan Temon (Gambar 3).

2. Pada tingkat desa, desa terpilih adalah desa yang memiliki jumlah penduduk usia 10-14 tahun terbanyak di masing-masing kabupaten/kota.

3. Pada tingkat pedukuhan, sebaran responden dipilih berdasarkan pertimbangan proporsional.

Tahapan pemilihan lokasi penelitian tersebut secara rinci diilustrasikan pada Gambar 2. 
Umi Listyaningsih, Muhammad Arif Fahrudin Alfana,

Resti Pujihastuti, dan Hilma Amrullah

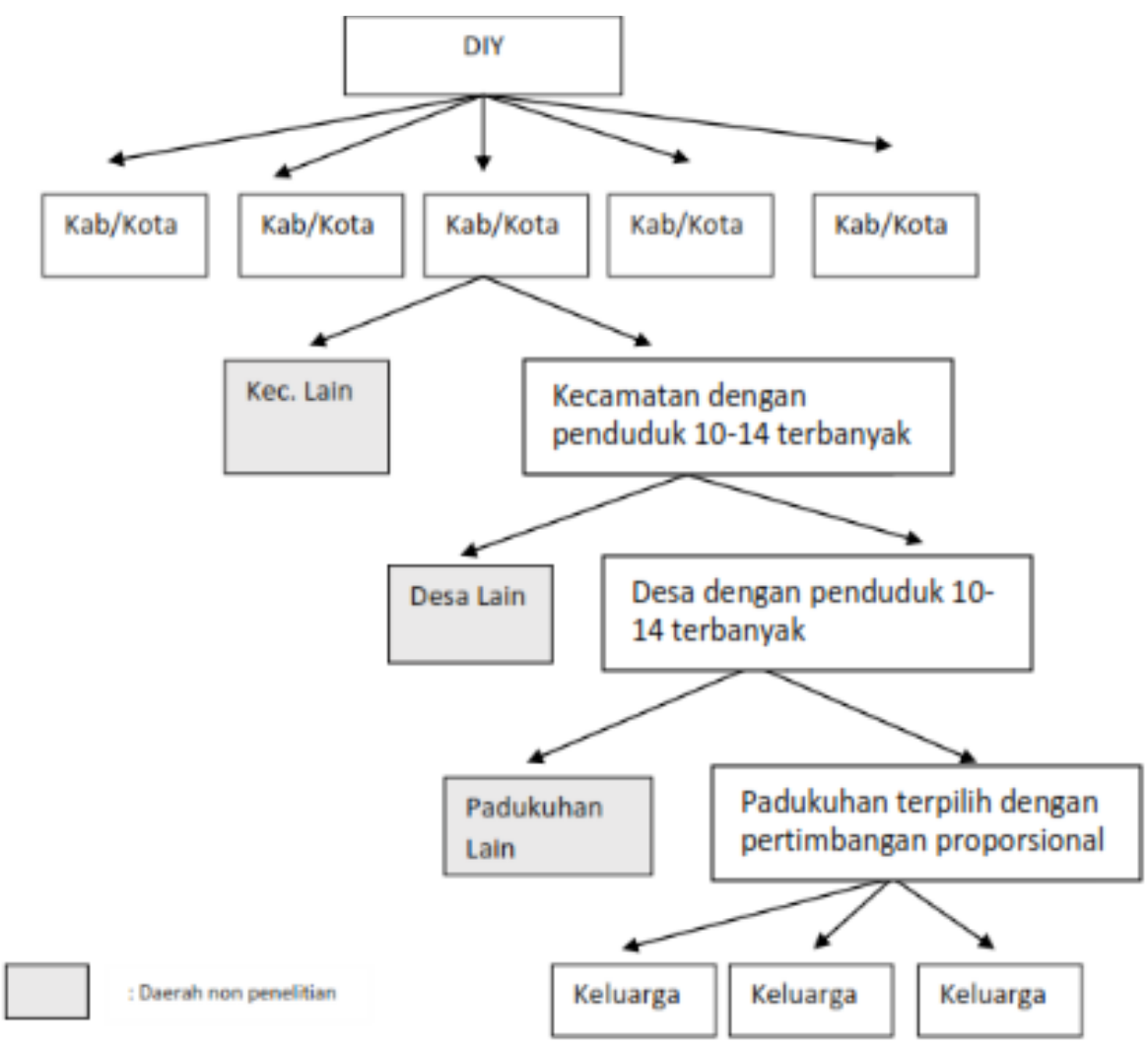

Gambar 2. Ilustrasi Pengambilan Sampel Populasi

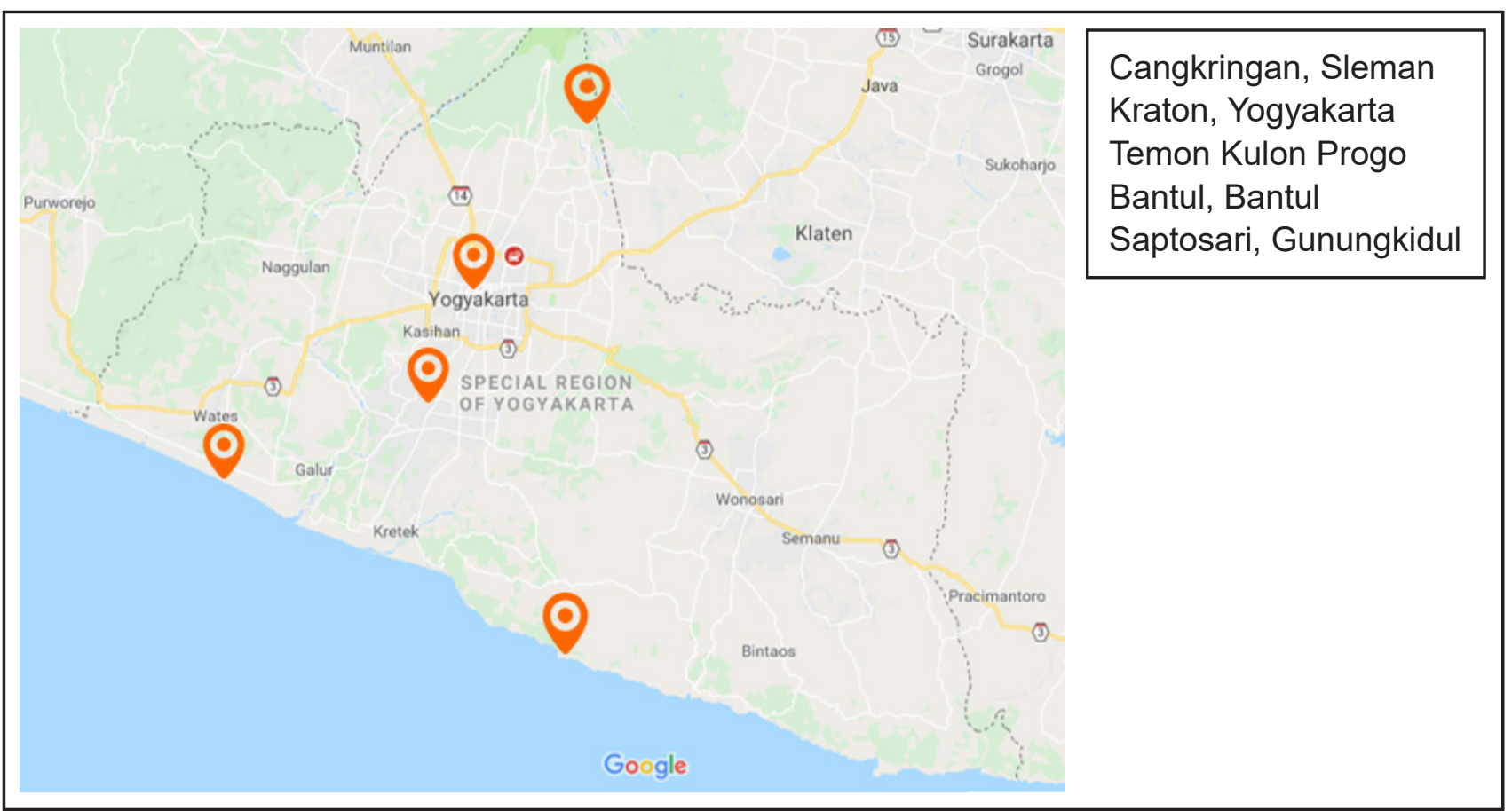

Gambar 3. Lokus Penelitian pada Tingkat Kecamatan di DIY 


\section{Pembahasan}

Penduduk Remaja Awal (Usia 10-14 Tahun) di Daerah Istimewa Yogyakarta

Masa remaja merupakan masa transisi awal menuju pribadi yang lebih matang. Masa remaja dibedakan menjadi tiga tahapan, yaitu1) remaja awal (early adolescent), 2) tahap remaja pertengahan (middle adolescent) dan 3) remaja akhir (late adolescent). Pembagian tersebut didasarkan pada perubahan psikososial yang terjadi secara umum pada remaja (Steinberg, 2017). Setiap tahapan tersebut memiliki perbedaan terkait hubungan antara kondisi sosial dan kesehatan mental/emosional remaja.

Masa remaja awal terjadi pada remaja usia 10-14 tahun. Masa remaja awal menjadi sangat penting karena perubahan awal kondisi psikososial terjadi dari tahapan sebelumnya, yaitu masa anak-anak (child). Batubara (2010) menjelaskan bahwa setidaknya ada perubahan psikologis yang terjadi pada remaja awal, antara lain; a.) krisis identitas; b.) jiwa labil; c.) meningkatnya kemampuan verbal untuk mengekspresikan diri; d.) pentingnya sahabat; e.) berkurangnya rasa hormat terhadap orangtua; f.) menjelaskan kesalahan yang dilakukan oleh orangtua; g.) mencari kasih sayang orang lain; h.) kekanakkanakan (childish); i.) pengaruh teman sebaya (peer group) pada cara hidupnya. Lebih lanjut, peran peer group pada masa ini sangat dominan. Mereka akan membentuk kelompok yang memiliki beberapa persamaan, seperti ciri-ciri, hobi, penampilan, dan sebagainya.

Jumlah remaja awal di DIY terhitung sangat besar, yaitu 7 persen dari total penduduk di DIY. Berdasarkan jumlah mutlaknya, remaja awal di DIY secara konstan mengalami kenaikan setiap tahun. Menurut data BPS, jumlah penduduk DIY usia 10-14 tahun pada 2017 sebesar 261,6 ribu jiwa. Setelah diproyeksikan, jumlahnya menjadi 344 ribu jiwa pada 2045. Hal ini berarti bahwa pertumbuhan jumlah remaja usia 10-14 tahun sebesar 4,28 persen per tahun atau lebih tinggi dari pertumbuhan total penduduk DIY yang hanya sebesar 1,8 persen per tahun.

Berdasarkan uraian tentang jremaja awal tersebut, hal ini mengindikasikan bahwa tantangan pengelolaan generasi muda di DIY di masa mendatang perlu mendapatkan perhatian lebih. Pengaruh negatif yang muncul dan merusak generasi muda harus diminimalisasi. Pola asuh orang tua yang tepat menjadi kunci keberhasilan bagi generasi di DIY secara khusus dan Indonesia secara umum di masa depan.

Pola Asuh Keluarga pada Anak Usia 10-14 Tahun

Pola asuh merupakan suatu metode yang diterapkan orang tua untuk mengontrol, membimbing dan mendampingi putra-putrinya menuju proses pendewasaan. Menurut Hurlock (1999), pola asuh dapat dikategorikan menjadi tiga macam,antara lain:

1. Pola asuh otoriter

Metode pengasuhan anak dimana orang tua memposisikan anak harus taat dan tunduk kepada semua keinginan orang tua. Anak bahkan memiliki porsi yang sedikit untuk sekedar berdiskusi dengan orang tua terhadap segala tugas, hak dan kewajiban yang dibebankan kepada dirinya.

2. Pola asuh demokratis

Metode pengasuhan dimana orang tua membuka diri terhadap pendapat anaknya. Musyawarah antara orang tua dan anak diutamakan demi kebaikan bersama. 
3. Pola asuh permisif

Metode pengasuhan orang tua dimana anak diberikan kebebasan dalam melakukan kehendaknya. Anak diberikan keleluasaan untuk mengatur kehidupannya dan cenderung kurang mendapatkan pengarahan dari orang tua. Akibatnya, jika hal ini dibiarkan, potensi anak untuk melakukan penyimpangan norma sangat besar karena anak tidak dapat menyesuaikan diri dengan aturan dan norma yang berlaku di masyarakat. Anak yang diasuh dengan metode ini cenderung akan tumbuh dengan sikap yang tidak disiplin. Pola asuh seperti ini lazim di masyarakat sebagai pola asuh dengan tipe memanjakan anak.

Selain ketiga pola asuh tersebut, menurut Baumrind (1971), terdapat satu pola asuh yang disebut acuh (neglectful/). Biasanya orang tua yang menerapkan pola asuh ini tidak memberikan waktu dan biaya yang cukup untuk anaknya. Orang tua lebih dominan menggunakan waktunya untuk bekerja daripada mengurus anaknya. Orang tua cenderung menelantarkan anaknya dan kurang memberikan perhatian kepada anaknya, baik secara fisik maupun psikologis.

Berdasarkan hasil survei yang dilakukan, hampir tidak ada keluarga yang hanya menerapkan satu pola asuh untuk mendidik anaknya. Hal ini berarti bahwa ada kombinasi metode pola asuh orang tua/keluarga dalam mendidik anak-anak mereka. Meskip demikian, dominasi pada salah satu pola asuh anak akan tetap terlihat, yaitu orang tua/keluarga tersebut cenderung ke pola asuh demokratis, otoriter, permisif atau acuh. Gambar 4. menunjukkan bahwa sebagian besar orang tua di daerah kajian mendidik anaknya dengan pola asuh demokratis (Gambar 4.). Sebesar 49 persen dari seluruh responden mengaku mendidik anaknya dengan pola asuh demokratis. Pola asuh ini

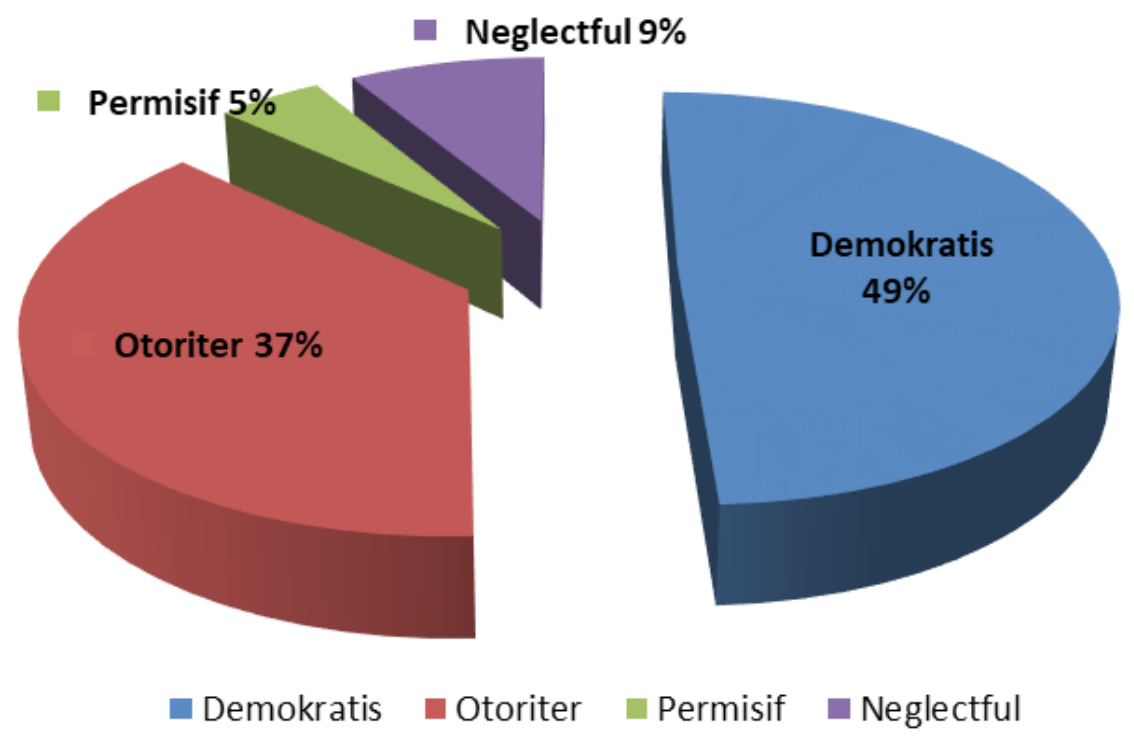

Sumber: Survei Lapangan, 2018

Gambar 4. Gambar Pola Asuh Keluarga di Daerah Istimewa Yogyakarta 
dicirikan dengan orang tua yang mendorong anak untuk hidup mandiri, namun tetap membuat batasan. Selain itu, beberapa ciri lain yang diterapkan adalah memberikan kontrol tetapi bersikap fleksibel, mendengarkan pembicaraan dan pendapat anaknya, serta menunjukkan dukungan atas perilaku anak yang dinilai positif untuk dilakukan.

\section{Pola Asuh Demokratis di Daerah Istimewa Yogyakarta}

Para orang tua menggunakan pola asuh demokratis karena mereka ingin mengajarkan anak untuk hidup secara mandiri, namuntetap melibatkan anak sebagai bagian dari proses pembelajaran hidup. Husada (2013) menyatakan bahwa orang tua/keluarga yang mendidik anak dengan pola asuh demokratis cenderung memperlakukan anak agar mereka bertanggung jawab atas apa yang mereka lakukan. Selain itu, para orang tua cenderung mendorong anak untuk bebas meskipun tetap memberikan batasan-batasan kepada anak tentang apa yang boleh dilakukan dan tidak.

Pola asuh demokratis sangat wajar menjadi pola asuh yang paling dominan dilakukan oleh orang tua kepada anaknya karenapola asuh ini memiliki peran yang baik dalam kehidupan anak. Peran tersebut berkaitan dengan kebaikan dalam hal prestasi belajar, kedisiplinan, kecerdasan emosi, perilaku prososial sampai perilaku seksual. Sari (2008), melalui survei yang dilakukan di SMU Pangudi Luhur Sedayu, menjelaskan bahwa terdapat korelasi positif antara pola asuh demokratis dan prestasi belajar siswa. Hal yang sama juga diungkapkan oleh David, Matulessy dan Pratikto (2014) bahwa pola asuh demokratis yang diterapkan oleh orang tua/keluarga memiliki korelasi positif yang sangat signifikan terhadap motivasi prestasi sampai tingkat mahasiswa. Temuan lain juga menjelaskan bahwa pola asuh demokratis memiliki signifikansi yang besar dan berkorelasi positif dengan variabel kemandirian anak.

Pola asuh demokratis juga memiliki hubungan yang positif terhadap variabel kedisiplinan, kecerdasan emosi, perilaku prososial, dan perilaku seksual. Berkaitan dengan kedisiplinan, pola asuh demokratis membentuk karakter kedisiplinan anak. Berdasarkan penelitian yang dilakukan Filisyamala, Hariono dan Ramli (2016) dengan subjek penelitian berupa anak-anak Sekolah Dasar, pola asuh demokratis mempengaruhi kedisiplinan anakdengan wujud ketaatan anak terhadap peraturan yang dibuat, baik di rumah maupun di sekolah.

Berkaitan dengan kecerdasan emosi dan perilaku pro-sosial, Husada (2013) menyatakan bahwa variabel pola asuh demokratis memiliki hubungan signifikan dengan variabel kecerdasan emosi dan perilaku pro-sosial. Husada (2013) juga menjelaskan bahwa remaja yang tumbuh dalam pola asuh keluarga yang demokratis cenderung memiliki kecerdasan emosi dan jiwa prososial dibandingkan remaja dengan pola asuh lainnya. Berkaitan dengan perilaku seksual, pola asuh demokratis memiliki hubungan yang kuat dengan variabel ini. Wulandari (2010) menjelaskan dalam studi yang dilaksanakan di Gamping Yogyakarta, bahwa jika pola asuh ini dilaksanakan dengan baik oleh orang tua, maka perilaku seksualitas remaja akan turun. Hal ini sejalan dengan penelitian Mayasari (2015) di Semarang, bahwa ada korelasi yang kuat antara pola asuh demokratis dan moralitas remaja. Semakin tinggi penerapan pola asuh demokratis, maka semakin baik moralitas remaja di keluarga tersebut. 
Pola asuh demokratis paling banyak diterapkan oleh keluarga di Daerah Istimewa Yogyakarta. Berdasarkan tingkat kabupaten/ kota, para orang tua di Kabupaten Sleman tercatat paling banyak menerapkan pola asuh ini. Dari seluruh responden yang diwawancarai di Sleman, 70 persen keluarga mengaku menerapkan pola asuh tipe demokratis. Cara yang paling dominan dilakukan orang tua adalah bersikap akrab dengan anak, membimbingnya agar terus mandiri, menerima pendapat anak meskipun berbeda, dan mengingatkan anak ketika mereka lupa dengan kewajibannya.

Keluarga yang menerapkan pola asuh demokratis tergolong mampu/tidak miskin secara ekonomi. Ukuran kemiskinan tersebut berdasarkan BPS (Badan Pusat Statistik) 2018 dengan garis kemiskinan di DIY sebesar Rp 409.744/kapita/bulan. Semua responden yang menerapkan pola asuh demokratis memiliki kendaraan bermotor dan hampir sepertiga dari responden memiliki mobil pribadi. Berdasarkan kepemilikan lahan tempat tinggal, 75 persen responden memiliki lahan sendiri dan hanya sekitar 5 persen memiliki rumah kontrak atau tinggal bersama saudara.

PolaAsuh OtoriterdiDaerah Istimewa Yogyakarta

Pola asuh tipe ini juga sering diterapkan oleh beberapa keluarga di DIY. Meskipun pola asuh otoriter dinilai dapat membuat anak tidak mandiri, tetapi beberapa penelitian justru menunjukkan fakta sebaliknya (EI Hafiz dan Almaududi, 2015). Penelitian Chao (2001), misalnya, menjelaskan bahwa pola asuh otoriter berdampak positif pada keluarga generasi kedua Cina dan keluarga Eropa-Amerika. Dampak tersebut terlihat dari adanya kedekatan hubungan antara anak dan orang tua.
Dampak positif lain dari pola asuh otoriter bagi anak adalah anak lebih matang secara emosi, lebih agresif dan semakin mandiri. Penelitian Zazimah (2015) menjelaskan bahwa pola ini memiliki korelasi positif dengan agresivitas anak usia 4-5 tahun. Hidayati (2014) juga menjelaskan bahwa pola asuh ini memiliki korelasi positif dengan kemandirian dan kecerdasan pada anak SD. Penelitian lainnya, seperti penelitian El Hafiz dan Almaududi, menunjukkan bahwa pola asuh otoriter ini memiliki pengaruh positif terhadap kematangan emosi dengan dimoderatori kesabaran (2015). Sedangkan As'ari (2015) menemukan adanya korelasi negatif antara pola asuh otoriter dengan kemandirian anak SMK. Berdasarkan inkonsistensi hubungan tersebut, Baumrind (1968) menjelaskan bahwa pola asuh otoriter masih relevan dan berdampak baik jika diterapkan pada anak usia awal. Sedangkan penerapan pola asuh otoriter pada anak yang sudah memasuki usia remaja dianggap tidak cocok lagi untuk diterapkan.

Berdasarkan hasil penelitian ini, pola asuh otoriter di DIY berada dalam kategori tinggi. Sebanyak 37 persen keluarga mengaku telah menerapkan pola asuh ini untuk mendidik anak-anaknya. Hal ini dinilai wajar karena populasi dari penelitian ini adalah anak usia 10-14 tahun (SD) sampai kelas 2 SMP. Dengan demikian, hal ini sangat mungkin bagi orang tua/keluarga untuk menerapkan pola asuh otoriter pada anaknya, terutama pada mereka yang masih berada pada jenjang sekolah dasar.

Berdasarkan kabupaten/kota, para keluarga/orang tua di Kabupaten Gunung Kidul tercatat paling banyak menerapkan pola asuh ini. Sedangkan dari seluruh responden yang diwawancarai di Sleman, 60 persen keluarga mengaku telah menerapkan pola 
asuh ini. Cara yang paling banyak dilakukan adalah mengawasi kehidupan anaknya dengan ketat, mewajibkan anak berperilaku sesuai keinginan orang tua dan para orang tua terkadang memaksakan kehendak anakanaknya. Secara ekonomi, keluarga yang menerapkan pola asuh ini tidak lebih baik disbanding keluarga yang menerapkan pola asuh demokratis. Meskipun 98 persen orang tua tersebut memiliki motor, tetapi hanya 16 persen yang memilki mobil.

Pola Asuh Permisif dan Acuh di Daerah Istimewa Yogyakarta

Kedua pola asuh ini sangat sedikit diterapkan di DIY, yaitu gabungan keduanya hanya sebesar 14 persen. Tipe permisif dan tipe acuh merupakan hal yang bertolak belakang. Di satu sisi, orang tua memanjakan anaknya, tetapi di sisi lain mereka tidak peduli atau acuh dalam mengurus anaknya.

Pola asuh tipe permisif dicirikan dengan orang tua yang memberikan kebebasan anaknya untuk berkehendak, dominasi pada anak serta sifat yang cenderung memanjakan anak. Meskipun pola asuh ini dinilai memiliki banyak hal negatif, tetapi menurut Rahman, Mardhiah dan Azmidar (2015), pola asuh ini tetap memiliki aspek positif. Aspek tersebut dapat dilihat pada kecerdasan emosional remaja. Kecerdasan emosional didefinisikan sebagai kemampuan untuk memotivasi diri sendiri, memiliki kemampuan untuk bekerja sama dengan orang lain, berempati terhadap orang lain dan kemampuan untuk mengatur emosi. Hasil penelitian Rahman, Mardhiah dan Azmidar (2015) menjelaskan bahwa meskipun perannya kecil (10 persen), tetapi pola asuh ini masih memberikan pengaruh positif bagi remaja tahap akhir.
Sedangkan pola asuh tipe acuh dianggap paling berisiko dan paling banyak menimbulkan efek negatif bagi anak. Hasil penelitian dari Veronika (2012) menyebutkan bahwa pola asuh tipe acuh akan meningkatkan efek negatif bagi remaja terkait perilaku cybersex. Widya (2017) juga menjelaskan bahwa pola asuh tipe acuh akan menyebabkan adanya keretakan hubungan antarsaudara kandung pada usia remaja dalam satu keluarga. Begitu pula dengan penelitian Sandi (2016) yang mengatakan bahwa pola asuh tipe acuh menjadi salah satu penyebab tingginya anak usia 13-21 tahun yang terjerumus pada perilaku alcoholic (minum minuman keras). Berdasarkan kabupaten/kota, para orang tua di Kabupaten Bantul tercatat paling banyak menerapkan pola asuh tipe ini. Dari seluruh responden yang diwawancarai di Bantul, 13 persen keluarga mengaku menerapkan pola asuh tipe ini.

\section{Kenakalan Anak dan Pola Asuh Orang Tua}

Hubungan pola asuh dan kenakalan anak terjawab dengan uji korelasi yang sesuaikarena data berdistribusi normal dan skala data dalam bentuk rasio. Berdasarkan uji tersebut terlihat bahwa tidak ada hubungan antara pola asuh dan kenakalan anak (Tabel 1) di sebagian besar kabupate/kota di DIY. Meskipun jenis pola asuh yang diterapkan berbeda, kondisi kenakalan anak tetap sama. Hal ini disebabkan oleh kombinasi pola asuh yang diterapkan orang tua, yaitu demokratis, otoriter, dan permisif. Pada usia tertentu, yaitu kurang dari 12 tahun, orang tua akan menerapkan pola asuh otoriter. Namun seiring dengan penambahan umur, pola asuh yang diterapkan pun berbeda dan cenderung bersifat bebas. Artinya, ketika anak sudah mampu membedakan mana 
Umi Listyaningsih, Muhammad Arif Fahrudin Alfana,

Resti Pujihastuti, dan Hilma Amrullah

Tabel 1. Hubungan antara Pola Asuh dan Kenakalan Anak

\begin{tabular}{lcccccc}
\hline $\begin{array}{l}\text { Hubungan } \\
\text { antarvariable }\end{array}$ & $\begin{array}{c}\text { Kota } \\
\text { Yogyakarta }\end{array}$ & Sleman & Bantul & $\begin{array}{c}\text { Kulon } \\
\text { Progo }\end{array}$ & $\begin{array}{c}\text { Gunung } \\
\text { kidul }\end{array}$ & Total \\
\hline $\begin{array}{l}\text { Pola asuh - } \\
\text { kenalan anak }\end{array}$ & $\begin{array}{c}\text { Tidak } \\
\text { signifikan }\end{array}$ & $\begin{array}{c}\text { Tidak } \\
\text { signifikan }\end{array}$ & $\begin{array}{c}\text { Tidak } \\
\text { signifikan }\end{array}$ & $-0,45$ & $\begin{array}{c}\text { Tidak } \\
\text { signifikan }\end{array}$ & $\begin{array}{c}\text { Tidak } \\
\text { signifikan }\end{array}$ \\
\hline
\end{tabular}

Sumber: Data Primer, 2018

yang baik dan benar, orang tua cenderung memberi kebebasan kepada anak, dengan tetap melakukan pengawasan.

Pola asuh dan kenakalan anak memiliki hubungan yang signifikan atau nyata di Kabupaten Kulon Progo. Terdapat arah hubungan negatif, yaitu pola asuh permisif dan acuh akan melahirkan kenakalan anak dibandingkan dengan pola asuh demokratis. Temuan ini sejalan dengan penelitian yang dilakukan Rahmat (2015) dan Utami dan Raharjo (2019). Rahmat (2015) menyebutkan bahwa pola asuh demokratis akan menekan potensi kenakalan anak. Sedangkan Utami dan Raharjo (2019), melalui penelitiannya di Lembaga Pemasyarakatan Anak (LPA), menyatakan bahwa salah satu penyebab kenakalan anak adalah pola asuh orang tua yang permisif dan acuh. Hal ini berarti bahwa untuk menekan kenakalan anak, orang tua harus memenuhi keinginan anak dengan tetap melakukan pengawasan dan perhatian. Kombinasi pola pengasuhan harus dilakukan dengan tipe pengasuhan demokrastis yang lebih dominan dibandingkan tipe pola asuh lainnya.

\section{Kesimpulan}

Hasil penelitian ini menunjukkan bahwa sebagian besar orang tua di daerah kajian mendidik anaknya dengan pola asuh demokratis. Daerah yang banyak menerapkan pola asuh ini adalah Kabupaten Sleman. Selain pola asuh demokratis, pola asuh otoriter juga diterapkan oleh para orang tua di DIY. Pola asuh otoriter ini masih bisa diterapkan untuk anak usia awal, namun tidak lagi cocok jika diterapkan pada anak yang sudah memasuki usia remaja pertengahan sampai akhir. Berdasarkan persentase, 37 persen responden mengaku mendidik anaknya dengan pola asuh otoriter. Responden yang banyak menerakan pola asuh ini adalah responden yang berasal dari Kecamatan Saptosari Gunung Kidul. Sedangkan pola asuh permisif dan acuh merupakan pola asuh yang paling sedikit digunakan oleh responden di seluruh daerah kajian karenakedua pola asuh ini memiliki efek negatif yang lebih banyak dari dua pola asuh lainnya. Pola asuh permisif akan menyebabkan anak menjadi manja, sedangkan pola asuh acuh akan menyebabkan anak susah diatur dan bertindak sesuai keinginan mereka. Untuk mencegah kenakalan anak, orang tua harus menerapkan tipe pola asuh kombinasi sesuai tahapan usia anak. Meski demikian, ketika menerapkan pola asuh kombinasi, pola asuh demokratis harus lebih dominan dari pola asuh lainnya.

\section{Ucapan Terima Kasih}

Tulisan ini adalah bagian dari hasil penelitian Hibah Kerjasama BKKBN dengan 
Fakultas Geografi UGM yang berjudul "Pola Pengasuhan sebagai Pembentuk Karakter dalam Pencegahan Kenakalan Anak" yang didanai pada tahun 2018. Penulis mengucapkan terima kasih kepada beberapa pihak, seperti Prof. Rizal Damanik, Dr. Sukamdi, M.Sc., dan Dr. Agus Joko Pitoyo, M.A atas bantuan, bimbingan serta masukan yang diberikan selama penulisan.

\section{Daftar Pustaka}

As'ari, M. H. 2015. Hubungan antara Pola Asuh Otoriter dengan Kemandirian. Skipsi. Surakarta: Universitas Muhammadiyah Surakarta.

Batubara, J.R.L. 2010. Adolescent Development (Perkembangan Remaja). Sari Pediatri. Volume 12, No.1, Juni 2010. Hal. 21-29. e-ISSN 2338-5030.

Baumrind, D. 1971. Current Patterns Of Parental Authority. Developmental Psychology Monographs, 4 (1, Pt.2). Hal. 1-103. http://dx.doi.org/10.1037/ h0030372.

BPS. 2018. Indeks Pembangunan Manusia 2017. Jakarta: Badan Pusat Statistik. ISSN: 2086-2369.

BPS. 2018. Proyeksi Penduduk Indonesia 2015-2045 Hasil SUPAS 2015. Jakarta: Badan Pusat Statistik, Kementerian PPN/ Bappenas dan UNFPA. ISBN: 978-602438-189-9.

Chao, R. K. 2001. Extending Research on the Consequences of Parenting Style for Chinese Americans and European Americans. Child Development. Volume 72(6), 1832-1843.

Darwin, M. Ekawati, H. dan Khabib, F. 2017. Membangun Relasi Digital antara Orang Tua Siswa dengan Sekolah dalam Penanganan Tawuran Pelajar di
Yogyakarta. Populasi. Volume 25 Nomor 2 2017. Hal. 1-23. e-ISSN: 2476-941X.

David, L.E.V., Matulessy, A dan Pratikto, H. 2014. Pola Asuh Demokratis, Kemandirian dan Motivasi Berprestasi pada Mahasiswa. Persona, Jurnal Psikologi Indonesia. Januari 2014. Vol. 3. No. 01. Hal. $65-70$.

El Hafiz, S. dan Almaududi, A.A. 2015. Peran Pola Asuh Otoriter terhadap Kematangan Emosi yang Dimoderatori oleh Kesabaran. Humanitas. Vol. 12 No. 2 . Hal. 130-141. ISSN 1693-7236.

Filisyamala, J., Hariono dan Ramli, M. 2016. Bentuk Pola Asuh Demokratis Dalam Kedisiplinan Siswa SD. Jurnal Pendidikan: Teori, Penelitian, dan Pengembangan. Volume: 1 Nomor: 4 Bulan April Tahun 2016 Hal. 668-672. e-ISSN: 2502-471X.

Giyarsih, S.R. and Alfana, M.A.F. 2013. The Role Of Urban Area As The Determinant Factor Of Population Growth. Indonesian Journal of Geography. Vol 45, No.1, June 2013 : 38 - 47. ISSN 0024-9521.

Hidayati, N.I. 2014. Pola Asuh Otoriter Orang Tua, Kecerdasan Emosi, dan Kemandirian Anak SD. Persona: Jurnal Psikologi Indonesia. Vol 3, No 01 (2014). Hal. 1-8. DOI: https://doi.org/10.30996/persona. v3i01.364.

Hurlock, E. 1999. Psikologi Perkembangan Suatu Pendekatan Sepanjang Rentang Kehidupan. Jakarta: Erlangga.

Husada, A. K. 2013. Hubungan Pola Asuh Demokratis dan Kecerdasan Emosi dengan Perilaku Prososial pada Remaja. Persona, Jurnal Psikologi Indonesia. Sept. 2013, Vol. 2, No. 3. Hal $266-277$.

Mayasari, F. 2015. Hubungan antara Pola Asuh Demokratis Orang Tua Terhadap Moralitas pada Remaja. Fakultas Psikologi Universitas Semarang. 
Rahman, U., Mardhiah dan Azmidar. 2015. Hubungan antara Pola Asuh Permisif Orangtua dan Kecerdasan Emosional Siswa dengan Hasil Belajar Matematika Siswa. Auladuna, Vol. 2 No. 1 Juni 2015: 116-130.

Rahmat, H. 2015. Hubungan antara Pola Asuh dengan Kenakalan Remaja (Juvenile Delinquency) pada Siswa di SMA Negeri 2 Babelan. Skripsi. Universitas Bhayangkara Jakarta Raya.

Sandi, M. K. 2016. Dampak Pola Asuh Permisif Orang Tua Terhadap Perilaku Minuman Keras Pada Remaja Usia 1321 Tahun di RT 26 Kelurahan Silaberanti Kecamatan Seberang Ulu I Palembang. Skripsi. Palembang: UIN Raden Patah Palembang.

Steinberg, L. 2017. Adolescence 11th Edition In The Fundamental Changes Of Adolescent: Biological Transition. New York: Mc Graw Hill.

Sari, R.P. 2008. Hubungan antara Pola Asuh Demoktratis dengan Prestasi Belajar Pada Remaja. Skripsi. Yogyakarta: Universitas Sanata Dharma.

Utami, A.C.N. dan Raharjo, S.T. 2019. Pola Asuh Orang Tua Dan Kenakalan Remaja. Jurnal Pekerjaan Sosial. Vol. 2. No: 1. Hal. 150 - 167. Juli 2019. ISSN: 2620-3367.

Veronika. 2012. Hubungan antara Pola Asuh Permisif Orangtua dengan Perilaku Cybersex Remaja Akhir. Skripsi. Malang: Jurusan Psikologi, Fakultas Pendidikan Psikologi, Universitas Negeri Malang.

Widya, N. 2017. Hubungan antara Persepsi terhadap Pola Asuh Permisif dengan Sibling Rivalry pada Remaja Akhir. Skripsi. Yogyakarta: Universitas Mercu Buana Yogyakarta.

Wulandari, I. 2010. Hubungan Pola Asuh Demokratis dengan Sikap terhadap
Perilaku Seksual Remaja. Skripsi. Yogyakarta: UIN Sunan Kalijaga.

Zazimah. 2015. Pengaruh Pola Asuh Otoriter Terhadap TingkatAgresivitas Anak Usia 4-5 Tahun Di RA Insan Harapan, Kecamatan Pandak, Kabupaten Bantul. Skripsi. Semarang: Universitas Negeri Semarang. 